\title{
"Sammenrotning"
}

\section{Kollektive aktioner og folkemassens tilsynekomst i dansk 1600-tals historie}

Af forskningschef, dr.phil. John T. Lauridsen

I europæisk historie og historieforskning er folkemassen, "the crowd" en forlængst etableret størrelse. ${ }^{1}$ Anderledes i Danmark, hvor konfliktniveauet siden Grevens Fejde i 1530'erne har været lavere end i de fleste andre europæiske lande. ${ }^{2}$ Den mere eller mindre regerlige folkelige "masse" syner af meget mindre i dansk historie, selv om den naturligvis er der, uden at der nødvendigvis skal være tale om konflikter. Massens tilsynekomst er nemlig ikke alene forbundet med utilfredshed og oprør. Den er tillige et led i autoritetsfremstillingen og magtrepræsentationen i så forskellige regimeformer sım den enevældige og den fascistiske stat. Både de enevældige konger og fascistlederne viste sig for massen, for folket. Massens tilsynekomst må forstås i to betydninger: Både som uønsket og ønsket af magtens indehavere.

Da der i 1986 udkom den første antologi om kollektive aktioner og protester i Danmark siden middelalderen, tog den sit kronologiske udgangspunkt ved $1720{ }^{3}$ I antologien blev massen kun opfattet i den første af de to betydninger, der er nævnt ovenfor. Nemlig som uønsket. Det er hensigten her at fører perspektivet et århundrede længere tilbage, udbrede opfattelsen af massen og skitsere dens ændrede roller i overgangen fra adelsvælde til enevælde.

Christian 4. efterlod ved sin død 1648 andet end skønne bygningsværker, nye byanlæg og en mægtig orlogsflåde. Til sønnen Frederik 3.s arv hørte også en stor statsgæld og et statsapparat med så mange ansatte som aldrig tidligere. Det var først og fremmest i København, rigets militære centrum, at antallet af statslige tjenere var vokset. Alene i de såkaldte Skipperboder og i Nyboder var permanent samlet 


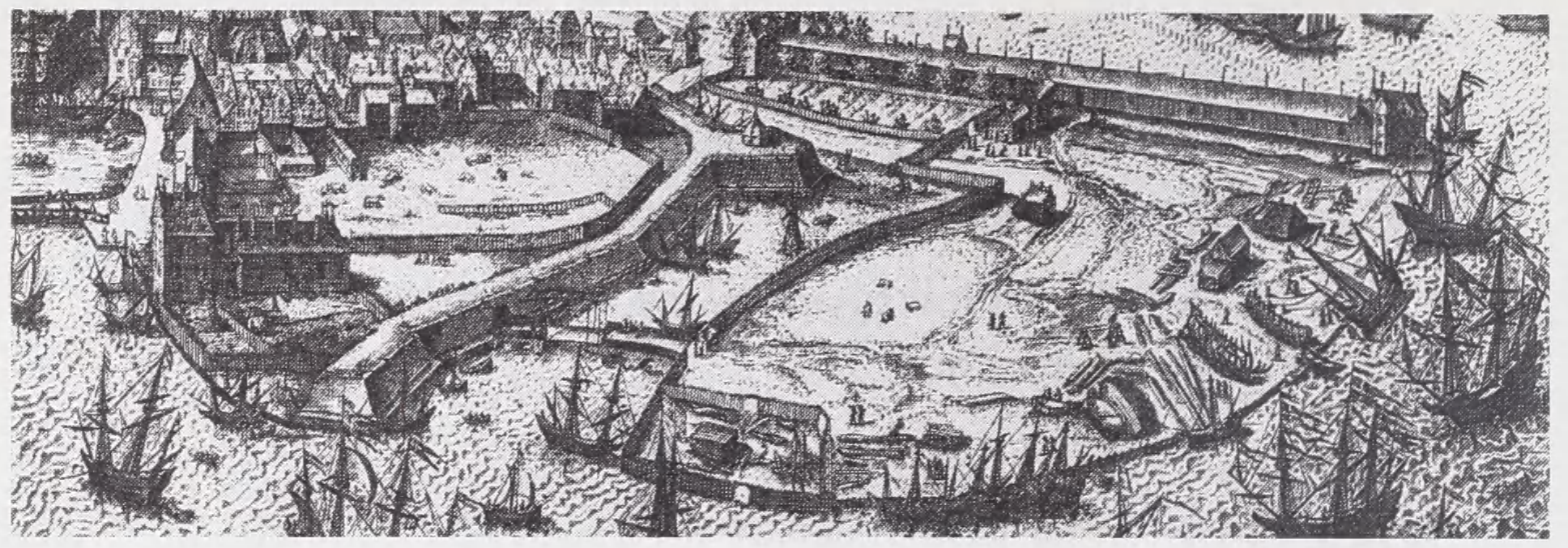

Flådeværftet Bremerholm, som det så ud i begyndelsen af 1600-tallet med tømmerplads og ophalingssteder. en lange bygning i baggrunden er reberbanen.

adskillige tusinde søfolk og andre, der gjorde tjeneste i orlogsflåden eller på Bremerholm, flådens hjemsted. Dertil føjede sig en garnison af soldater på omkring 4.000 mand. For at stå sig i kampen med ærkerivalen Sverige havde Christian 4. oprustet og opbygget et omfattende permanent militært apparat. ${ }^{4}$ Det var derfor en i bogstaveligste forstand omkostningskrævende arv, Frederik 3. overtog, da han blev kronet i Vor Frue kirke i København den 23. november 1648. En understregning af situationens alvor var det, at selve kongekronen havde været pantsat til købmænd i Hamborg og i hast måtte hentes til Købehavn til den højtidelige kroningsceremoni. ${ }^{5}$

For at mindske udgifterne søgte den nykronede konge at reducere mængden af statsansatte, en løsning der heller ikke i dag er ukendt. Alene på Bremerholm blev matrosernes antal nedskåret fra 1.500 til 600. Det var i sig selv alvorligt nok, men dertil kom, at staten var i restance med betalingen af lønnen. Naturligt nok trængte søfolkene sig på for at få deres tilgodehavende. En tid blev de holdt hen med løfter; de skulle bare vente til den i udlandet værende rigshofmester, Corfitz Ulfeldt, kom hjem. Han ville medbringe en stor sum penge fra Nederlandene, som herefter til gengæld slap for at betale told i Øresund. De penge kunne betale lønningerne. Det forestillede man sig i det mindste.

Ulfeldt kom til København i december 1649, men alligevel måtte bådsmændene og andre klare sig julen over uden løn. Misfornøjede samlede en stor skare søfolk sig foran Københavns slot, og da Ulfeldt kom ud fra en audiens hos kongen for at køre tilbage til sin bolig i Løvstræde, omringede de vognen og forlangte deres til- 
godehavende. Han havde jo haft mange penge med hjem, så ville de ikke med koner og børn sulte ihjel i denne dyre tid. Uden held søgte rigshofmesteren at dæmpe gemytterne med hele sin autoritet - først med gode ord og derefter med trusler om at sætte soldater ind. Skaren svarede trodsigt igen; de truede med at storme Ulfeldts gård, hvis de ikke fik, hvad der tilkom dem.

Fra slottets vinduer kunne man følge bådsfolkenes aktion. Det fik kongen til først at sende parlamentærer ned på pladsen. Det beroligede ikke gemytterne. Derpå måtte to rigsråder i egen høje person komme til stede og på kongens vegne love et kvart års løn. Da pengene virkelig straks blev udbetalt, faldt den ophidsede skare til ro, og man gik hver til sit. ${ }^{6}$

Det siger sig selv, at dette optrin, der havde involveret nogle af rigets mægtigste mænd, ikke kunne gå upåtalt hen. Rigsrådsrepræsentanter forhandlede ikke direkte med hverken kongens tjenere eller andre på gader og pladser, og da slet ikke under trusler. Den 1. februar 1649 udgik der en advarsel til alle bådsfolk i kongens tjeneste mod at samles og til sammen rotte og mod "endog vore fornemste tjenere på gaden og udi deres huse i hobetal at søge, forfølge og med ubeskedelige ord overfalde”. Gentog det sig, ville de blive straffet som oprørere. Havde de noget at forebringe, skulle det ske skriftligt, så ville de blive hjulpet efter sagens beskaffenhed. ${ }^{7}$ Straffen for oprør betød i praksis, at de kunne komme til at lide dødsstraf. Det var en yderst alvorlig forseelse.

Den meget selvbevidste Corfitz Ulfeldt brød sig ikke om den form for opmærksomhed, som søfolkene her havde vist ham. Det var krænkende for hans stand og anseelse. Især passede det ham ikke, da han havde været med til at disponere over de mange rare kontante penge på anden vis. Alene hans rejse til Nederlandene havde kostet den uhyre sum af 117.000 rigsdaler $^{8}$ (en bådsmandsløn var omkring 50 rigsdaler årligt). Den udgift skulle naturligvis først ud af verden, men derefter måtte en række danske og udenlandske storkøbmænd tilgodeses. De var alle Ulfeldts nære forretningsforbindelser og havde ydet staten varer og tjenester $\mathrm{i}$ tillid til hans forsikringer. Han havde været rundhåndet med forsikringerne og ikke taget det så nøje med priser og kvitteringer i den gamle konges sidste år. Det lukrerede statsleverandørerne på, og de oparbejdede uhyre tilgodehavender. ${ }^{9}$ Den nye konge måtte stå ved sit ansvar overfor disse kreditorer og se at få dem betalt. Det blev de også, i det mindste i et vist omfang - og alle andre måtte vente. Rentemester Peder Vibe 
beskrev i februar 1649 situationen således: "Baadsfolket og enhver Mand er malcontent uden de Marselis, Henrik Müller og nogle faa andre, som har faaet Indvisninger på de bedste Rigens Intrader, saa at i dette Aar resterer næppelig saa meget, som behøves til Kongens Hofhaltung". ${ }^{10}$ Marselis, Müller og nogle få andre var netop Ulfeldts handelspartnere.

Den venten huede ikke kongens tjenere, hvad enten de var søfolk, soldater eller lagerarbejdere. Det drejede sig om deres eksistensgrundlag. Blandt bådsfolkene var utilfredsheden fortsat stor, og bedre blev det ikke af, at flere afskedigedes. Det drejede sig i foråret 1650 om "de sletteste og de, der bedst kunne undværes", som det ligefremt og brutalt hed i fyringsordren den 10. april. Syv dage senere blev 240 personer, som havde tjent flåden, afskediget med et års løn og en restseddel. De øvrige fik igen udbetalt lidt af deres sold, men ikke nok til mere varigt at dæmpe misfornøjelsen. De udenlandske bådsfolk var så utilfredse, at de svor på, at de i tilfælde af krig ville tage tjeneste hos fjenden. Det førte til nye aktioner og en del rømninger. Af 431 udskrevne matroser i 1653 rømmede de 68. Også soldaterne aktionerede. Der var optøjer på Bremerholm - foruden den udeblevne løn, ville de have bedre mad. De blev anholdt. ${ }^{11}$ Året efter var rentemester Peder Vibe udsat for fysisk blokade. Han skrev 19. marts til Erik Krag: "Jeg kan ikke noksom beklage mig over den besværlighed, jeg har af alle, som har noget at fordre både hof-, Holmens- og tøjhustjenere, såvel som af arbejdsfolk og andre, som kronen er skyldig. Forgangen torsdag var der ved 150 af tøjhusfolket for min port, hvilken jeg måtte lukke til og skikke en af mine folk over graven gennem løngangen op til deres øvrighed på Tøjhuset at sætte styr på dem, hvilket og skete”. For at klare sig ud af den truende situation havde den adelige rentemester ganske enkelt måttet sende bud efter hjælp. ${ }^{12}$

Det var igen en helt utålelig situation for en af kongens fornemste tjenere - helt utænkelig blot et par årtier tidligere. Hvad var der sket? Hvori bestod det nye? Hvordan kunne disse kollektive aktioner opstå og hvorfor alene i København, men ikke i provinsen, hvor nøden var lige så stor? Forklaringen må søges i, at der for det første under Christian 4. havde udviklet sig flere og langt større statslige arbejdspladser i København end ude i landet, og med disse, for eksempel Bremerholm, var der opstået potentielle udgangspunkter for aktioner. Mange ansatte var nu permanent beskæftiget samlet på de store arbejdspladser, hvad enten det var omkring værftet, tøjhuset eller garnisonen. 


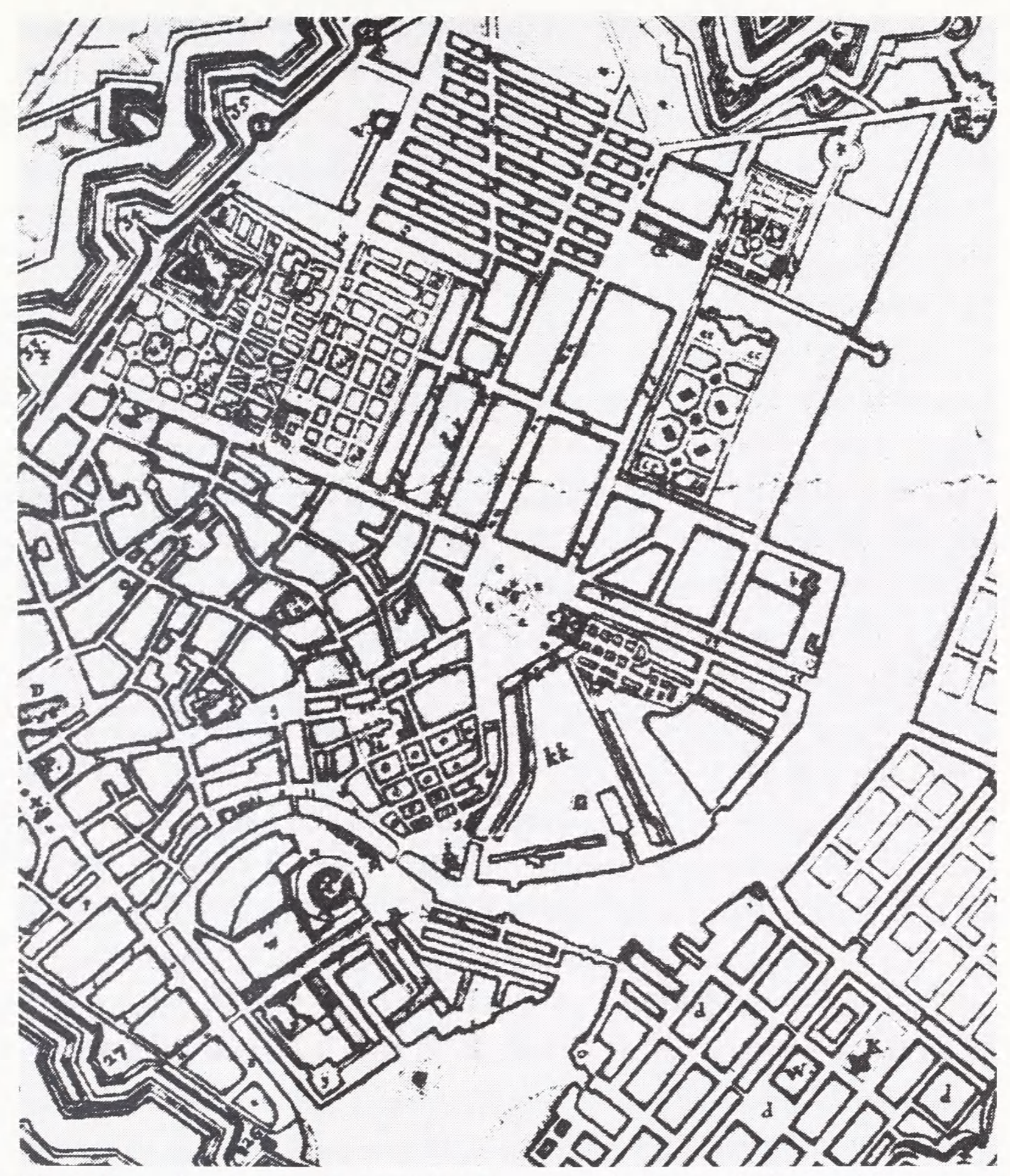

Udsnit af prospekt over København fra 1687. Man ser her placeringen af Nyboder, toldboden med den nyanlagte flådehavn. Nederst, overfor Bremerholm ses Skipperboderne.

Hertil kommer for det andet, at der med opførelsen af 130 dobbelthuse Skipperboderne - i årene efter 1614 og 614 Nyboderhuse mellem 1631 og 1648 var skabt den hidtil største planlagte boligkoncentration i Danmarks historie. ${ }^{13}$ Det var et tæt lavt rækkehusbyggeri af dimensioner. Karré efter karré var bygget efter en samlet overordnet plan. Der boede tusindvis af mennesker i disse to komplekser. Rækkehusene var bygget for at afhjælpe boligmanglen i hovedstaden, men egentligt 
også for at opretholde ro og orden. Alle beboere var i kongens tjeneste. Samlet på ét sted var søfolkene lettere at få fat på og dermed kontrollere. Den store befolkningskoncentration kom imidlertid til at virke mod sin oprindelige hensigt. Især Nyboder blev potentielt arnestedet for utilfredshed under de første enevoldskonger. Det nære samkvem mellem de dér boende familier, med fælles vilkår og problemer i forhold til arbejdsgiveren, staten, gav en helt ny baggrund for kollektiv optræden og samlet protest.

Som tredie og sidste faktor er Københavns befolkningsvækst og den stadig mere koncentrerede bydannelse. I takt med byens hastigt stigende indbyggertal - antallet steg fra 30.000 til 60.000 mellem 1660 og 1690 - blev flere og flere afhængige af lønindkomster i rede penge. I Nyboder kunne man delvis kompensere for den udeblevne månedsindtægt ved at dyrke sin lille have og leve af naturalier. Der var imidlertid ikke tilstrækkelig plads til haver, så de kunne dække et basalt fødevarebehov og tillige give noget at bytte med. Flere og flere blev i den forstand rene byboere. De var regulært på spanden, når kongen ikke lod sine tjenere betale. Her har vi de gnister eller det brændstof, der satte de kollektive aktioner og opløb i gang efter at bålet $\mathrm{i}$ form af sammenhobning af de ansatte i forvejen var lagt til rette. Hvor vigtige haverne i Nyboder i øvrigt var, fremgår af et projekt fra omkring 1656, hvor Nyboder blev foreslået udbygget til det dobbelte boligareal på samme grundstykke ved at nedlægge småhaverne og fordoble antallet af boder på dem i stedet. Så ville det ikke gå ud over gadebredden, men samtidig blev der tænkt på haverne. Det blev nemlig foreslået at give Nyboderfamilierne haver uden for Københavns befæstning. ${ }^{14}$ Forslagsstilleren har været klar over, at beboerne ikke kunne undvære haverne.

Hvordan skulle myndighederne klare problemerne i de nye boligdannelser? En karre-bebyggelse af Nyboders størrelse lod sig ikke bare opløse, og de statslige arbejdspladser blev større, ikke mindre i den følgende tid. I første omgang kom krigsrygterne og siden krigene med Sverige 1657-60 myndighederne til hjælp - de tog hele opmærksomheden - og efter 1660 havde den nu indførte enevælde en midlertidigt dæmpende virkning. Det var et militært diktatur, som slog voldsomt ned på al slags oprør og opsætsighed. Gemytterne holdtes i ave, men efter den nye krig med Sverige (1675-79) var det slut. Staten manglede penge, og dem der var, gik til andre formål, så lønningerne udeblev, helt eller delvis. Orlogsflådens søfolk samledes jævnligt i protest og forøvede "tumult og gevalt" i gaderne i 1680'erne. 


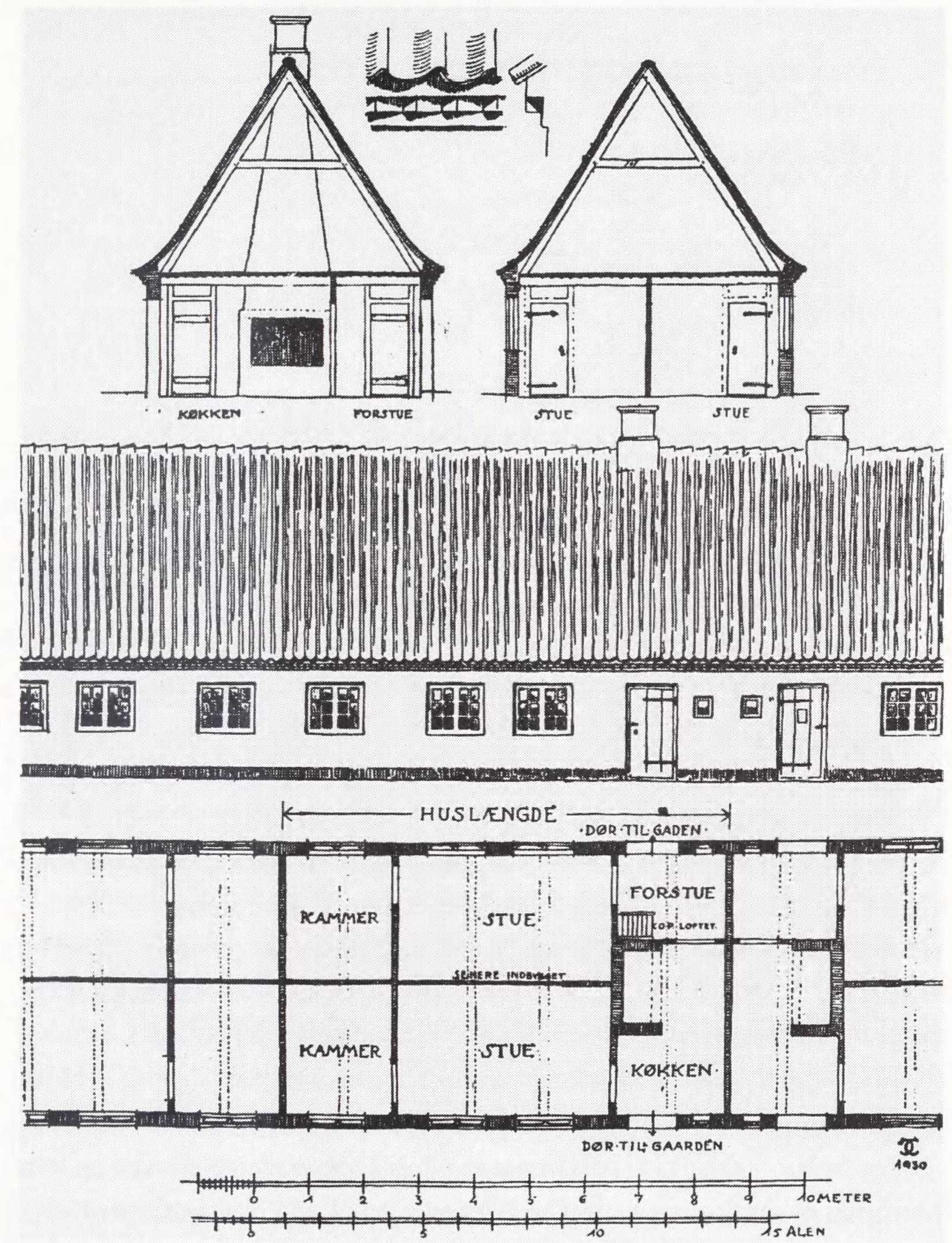

Plan af den tilbageværende længe fra Christain 4.s tid. Før opdelingen rådede hver familie over ca. 40 $\mathrm{m}^{2}$, men skillevæggene, der blev sat op under Frederik 3. og Christian 5. reducerede arealet til ca. 15 $\mathrm{m}^{2}$ pr. familie - hertil skal dog lægges den fælles forstue og det fælles køkken. Tegning i O. Alstrup og Ch. Christensen Nyboderfolket. 1930. 


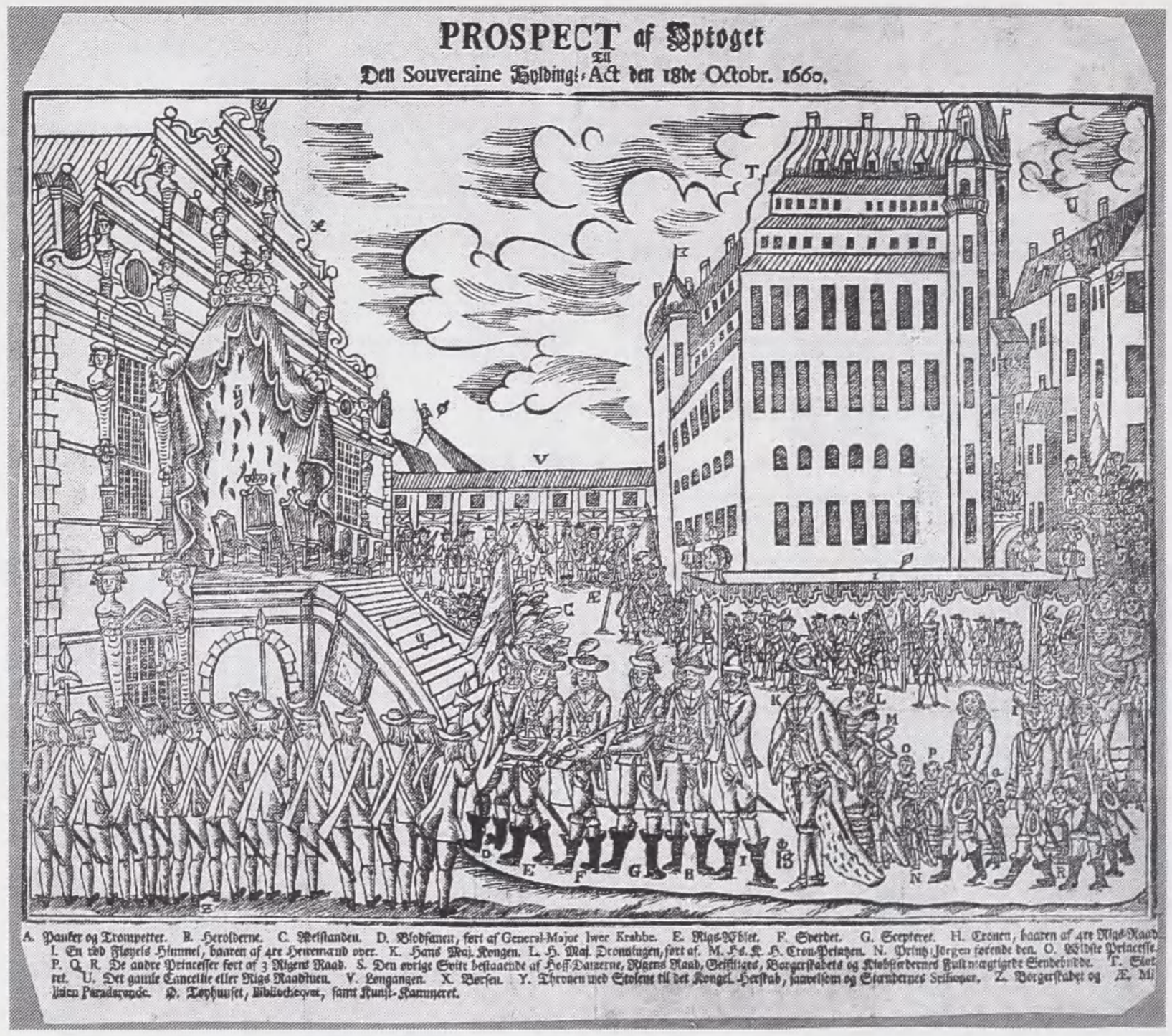

Arvehyldningen 1660. Etbladstryk. Processionen befinder sig mellem Børsen og Københavns Slot.

Det kom i de følgende år flere gange til egentlige gadekampe mellem matroser og udkommanderede soldater. De var så voldsomme, at der var både sårede og døde på begge sider. Således i 1686 og navnlig i Skt. Hans aften 1690 i Nyboder, hvor befolkningen traditionen tro havde rejst en majstang og forlystede sig med dans. Et klammeri mellem en soldat og en pige, han nappede vist noget fra hende, udløste utilfredsheden, og snart var hele kvarteret i oprør. Økser, knive, stænger og sten blev brugt mod soldaternes sabler og bajonetter, og til sidst blev musketter taget $\mathrm{i}$ brug. Vagten ved Østerport blev angrebet så målbevidst af Nyboder-folkene, at den måtte fortrække. Officerer søgte at mane til ro og orden, men trods det varede kampene hele natten og næste dag med. Den næste nat patruljerede hestgarden. ${ }^{15}$

En ting var, at matrosernes lønninger udeblev - statens gæld til dem var i 1693 oppe på 267.000 rigsdaler - en anden, at de efterhånden fik deres boligforhold 
stærkt forringet. Regnes boligen som en del af lønnen, og det kan vi roligt gøre, så faldt dens kvalitet drastisk. For det første blev boderne ikke vedligeholdt. Når der ikke var penge til al muligt andet, var der heller ikke penge til dette. I 1682 havde situationen nået et punkt, så admiralitetet lod en kommission aflægge besøg i Nyboder. Et resultat af dette besøg var, at der omgående blev sendt 3.000 tagsten til boderne. Det hjalp lidet. 1691 indberettede søetatens bygmester Christoffer Gross, at bygningerne var utjenlige til beboelse! På den måde fik han gennemtrumfet afsættelse af et årligt beløb til vedligeholdelse. ${ }^{16}$ For det andet blev hver "bod" i Nyboder, som af Christian 4. var bestemt for en familie, under Frederik 3. og Christian 5. delt op til to familier. Der blev ganske enkelt sat en træskillevæg op på langs gennem husene, så familierne var fælles om køkken og forstue. Endda trak det ud med opsætningen af disse skillevægge selv efter, at der var sat to familier ind. Det kneb med at få råd til skillevæggen i bodernes store stue. Det nærede yderligere utilfredsheden. Mindst det dobbelte antal familier blev klumpet sammen på samme plads, og boede enten på "mørkesiden" mod nord eller "solsiden" mod syd. Ovenpå boede så de lejere, som blev taget ind for at tjene nogle ekstra skilling. Med opdelingen blev det livsvigtige havestykke mindst halveret, og vilkårene blev yderligere forringet. Opdelingen var tilendebragt før 1700 og vel bl.a. andet accelereret af, at skipperboderne blev brandskadede 1690 og de resterende boder solgt 1694, så beboerne måtte overføres til Nyboder. ${ }^{17}$

Presset på dette kvarter og dets beboere var øget ganske betydeligt under Christian 5. Det er hævet over enhver tvivl. ${ }^{18}$

For at få en ende på demonstrationer og optøjer blandt søfolkene greb myndighederne mod århundredets slutning til en militarisering af centret for uroen, nemlig hele Nyboder-kvarteret, i den i forvejen overbefolkede by. Med fast hånd blev husene omfordelt, håndværkere for sig, tøjhusfolk for sig osv., sammenspiste beboere blev adskilt. De enkelte kompagnier i flåden fik tildelt hver et bestemt antal karreer. Opsynet og kontrollen med beboerne blev skærpet. Der blev ansat en inspektør. Endelig blev en vagtbygning ved Adelgade med arrest (i Nybodermunde "Hundehullet") bemandet med tolv soldater og en løjtnant. De skulle sikre roen i kvarteret. For at kunne afsvale ophidsede gemytter blev der til brug for mestermanden 1688 opsat fire pæle med hals- og håndjern på "mest forbifaldende steder". ${ }^{19}$ Der kunne ikke være tvivl om, hvordan sammenrotning ville blive behandlet. 
Vagtmandskabets nidkærhed og optræden i tjenesten kom i sig selv til at give anledning til tumulter. Når det lød "det er vagten", da var det signal ikke blot til flugt, men også til hujen og skrigen. Den form for despekt for autoriteternes repræsentanter gav en vis tilfredsstillelse, men bragte ikke den manglende løn til veje.

Kun lidt hjalp det. Sammenrotning blandt statens ansatte blev en permanent del af arven efter Christian 4. til langt ind i 1700-tallet. I Nyboder ikke mindst.

Her dukker massen igen op i dansk historie og reagerer kollektivt. Uønsket af magthaverne. Det var ikke set siden Grevens Fejde over 100 år tidligere. Under en lang række af konger havde folkemassen kun været negligerede statister, som måske fik tilkastet nogle mønter, når kongelige blev kronet, begravet eller indgik ægteskab. Det store og kostbare ceremoniel med optog ved Christian 4.s kroning i august 1596 er et godt vidnesbyrd derom. Både de foreliggende beskrivelser af begivenheden og de samtidige stik og senere af Karel van Mander den ældre udførte gobeliner med fremstillinger deraf udgrænser folkemængden og gør de fornemme gæster til "folket". ${ }^{20}$ Det er ligeledes tilfældet ved "det stor bilager" i 1634, dobbeltbrylluppet hvor den udvalgte prins Christians bryllup med Magdalena Sibylla af Sachen og prinsesse Sofie Elisabeths med Christian von Pentz blev fejret, da der endnu ikke var ebbe i den kongelige kasse. ${ }^{21}$ Ved disse lejligheder var folkemassen tilskuere og statister ved festerne, men der blev ikke regnet videre med den. Det gjorde adelsvælden ikke. De øverste stænder præsenterede sig for hinanden og fremmede gæster ved sådanne lejligheder, ikke for folket. Det ville være under adelssamfundets værdighed. ${ }^{22}$

Bønderne skulle være repræsenteret ved Frederik 3.s hylding hylding 1648, men straks den rent formelle del var afviklet, fik de et andet kvarter end de andre stænder. De måtte godt blive usynlige igen.

Det ændrede sig efter 1660. Den enevældige konge var alle stænder overlegne, også adelen, og alles konge. Konge af Guds nåde. Nu var det folket, herunder adelen, kongen lod sig fremstille for. Massen blev ønsket ved bestemte lejligheder. Borgere, bønder og menigmand og alt tjenerskab. På det mest berømte billede af arvehyldingen den 18. oktober 1660, syner og fylder folkemassen meget som beskuere af den store begivenhed. Det er ganske tilsigtet, for det er det første møde i Danmarks-historien mellem kongen og folket, hofmaler Wolfgang Heimbach på bestilling har foreviget 
i 1666. Massen, folket er der som vidner, undersåtter og undergivne. Det er de også på den senere hofmaler Michael van Havens maleri af samme begivenhed. ${ }^{23}$ Von Havens maleri kunne endnu ved 1750 danne grundlaget for en folkelig fremstilling af den epokeskabende dag på et træskåret etbladstryk. ${ }^{24}$ Folket var varigt til stede gennem kunstnernes arbejder. Det blev fastholdt, og det blev ønsket fastholdt. Disse malere havde fået at vide eller vidste, hvad den royale arbejdsgiver ønskede.

Paradoksalt er det, at samtidig med at folket bliver trukket ind som passive beskuere til magtfremstillelsen for første gang, er det mere end tidligere svært for den samme magt at opretholde passiviteten i dele af befolkningen. Vel antastede de kongelige tjenere ikke kongens magt, de var ikke oprørere, men når de trods risikoen for hårde straffe gav deres utilfredshed til kende, udsprang det af et regulært materielt behov og fælles vilkår. Den uønskede handlende masse var genkommet ved samme tid, som den passive ønskede folkemasse havde fået tildelt en synlig plads i den enevældige magtrepræsentation.

Den enevældige magtstat havde denne modsætning indbygget i sin vækst og magtkoncentration. I en række europæiske lande udviklede det sig til farlige oprør, men aldrig i Danmark. Det blev kun til sammenrotninger, som dem vi her er vidne til på slotspladsen og i Nyboder. Hvorfor det er en helt anden og større historie.

Noter

Se f. eks. George Rudé: The crowd in history 1730-1848. Rev. ed. London 1981, John Stevenson: Popular disturbances in England 1700-1870, London 1979, Mark Harrison: Crowds and History, Cambridge 1988

2 Jfr. Erling Ladewig Petersen: Fra standssamfund til rangssamfund 1500-1700, Dansk socialhistorie 3, 1980.

3 Flemming Mikkelsen (red.): Protest og opror. Århus 1986. Jfr. min anmeldelse i Historie. Ny Rk. 18: 4, 1991, s. 675-79.

4 Leon Jespersen: 1600-tallets danske magtstat. E. Ladewig Petersen (red.): Magtstaten i Norden i 1600-tallet og dens sociale konsekvenser, 1984.

John T. Lauridsen: Marselis-konsortiet. En studie over forholdet mellem handelskapital og kongemagt i 1600-tallets Danmark, 1987, s. 94.
P. W. Becker (red.): Samlinger til Danmarks Historie under Frederik IIIs Regering 1, 1847 , s. 33, H. D. Lind: Kong Frederik den Tredjes Somagt. Det dansk-norske Søvarns historie 1648-1670, 1896, s. 29

Kjøbenhavns Diplomatarium 3, 1877. Udg. af O. Nielsen, s. 322.

$8 \quad$ Lauridsen 1987 , s. 242 n.18.

9 H. D. Lind: Underslæb på Bremerholm under Korfitz Ulfeldts Finansstyrelse. Historisk Tidsskrift 6. V, 1894-95.

10 Lind 1896, s. 24.

11 Lind 1896, s. 30f., $59 \mathrm{f}$.

12 Rigsarkivet, Danske Kancelli, Sjællandske Indlæg 19. marts 1954. Afskrift i Det kongelige Bibliotek, Additamenta $837 \mathrm{~b}-4^{\circ}$.

13 Jørgen H. P. Barfod: Christian IV's Nyboder, 1983. 
14 Orla Alstrup/Charles Christensen: Nyboderfolket, 1930, s. 16.

15 Barfod 1983, s. 61

16 Alstrup/Christensen 1930 , s. 30, Barfod 1983, s. 48-57.

17 Alstrup/Christensen 1930 , s. 16, 32, 39f., Barfod 1983, s. 37, $64 f$.

18 Jørgen H. Barfods konklusion for samme periode er: "Under Christian V var der således skabt ordnede forhold i langt større udstrækning end man tidligere havde kendt" (Barfod 1983, s. 68). Den sociale dimension mangler ganske i dette arbejde.

19 Barfod 1983, s. 61.

20 August Erich: Klarlige ov Visse Beskriffuelse Om den Stormectige Hoybaarne Forstis oc Herris Herr Christian den Fierdes ... Kongelige Kroning ... Kbh. 1598, Steffen Heiberg: Christian 4., 1988, s. 51-55
21 Charles Ogier: Det store bilager i Kjøbenhavn 1634. Memoirer og Breve 20. Udg. af Julius Clausen og P. Fr. Rist, Kbh. 1914.

22 Der findes ingen samlet behandling af den repræsentative offentlighed og hofkulturens ideologiske funktion under adelsvælden, men bl.a. foreligger Ole Kongsted: Den verdeslige "rex splendes". Musikken som repræsentativ kunst ved Christian IVs hof, Christian IVs Verden. Red. af Svend Ellehøj, 1988, s. 433464. Se i øvrigt henvisningerne hos Heiberg 1988, s. 464.

23 Analyser af malerierne i bl.a. Dansk Kunsthistorie 2, 1973,s. 219ff (Poul Eller).

24 V. E. Clausen: Det folkelige danske tresnit $i$ etbladstryk 1565-1884, 1985, s. 118, 147. 